\title{
KUALITAS KARAGINAN DARI RUMPUT LAUT Kappaphycus alvarezii PADA LOKASI BERBEDA DI PERAIRAN MALUKU TENGGARA
}

\section{The Quality of Carrageenan from Kappaphycus alvarezii at Different Locations in Southeast Maluku Waters}

\author{
Bayu Kumayanjati dan Rany Dwimayasanti \\ Loka Konservasi Biota Laut Tual, Pusat Penelitian Oseanografi - Lembaga IImu Pengetahuan Indonesia, \\ Jl. Merdeka - Watdek, Tual, Maluku Tenggara, Indonesia \\ *Korespondensi Penulis: bayujati.dj@gmail.com
}

Diterima: 5 Oktober 2017; Direvisi: 6 April 2018; Disetujui: 5 Juni 2018

\begin{abstract}
ABSTRAK
Rumput laut jenis Kappaphycus alvarezii merupakan jenis rumput laut yang dibudidayakan di Maluku Tenggara. Rumput laut jenis ini merupakan rumput laut penghasil karaginan. Penelitian ini bertujuan untuk mengetahui kualitas karaginan dari rumput laut $K$. alvarezii yang dibudidayakan di tiga lokasi di Maluku Tenggara, yaitu Letman, Letvuan dan Revav. Kualitas karaginan yang diamati antara lain rendemen, kadar air, kadar abu, viskositas, kekuatan gel, dan derajat putih. Rumput laut diekstrak dengan metode perlakuan alkali dengan larutan $\mathrm{NaOH}$ 9\%. Data yang diperoleh kemudian dianalisis dengan program statistik IBM SPSS Statistics 24 untuk mengetahui perbedaan kualitas karaginan dari tiga lokasi tersebut. Hasil penelitian menunjukkan bahwa kualitas karaginan dari tiga lokasi berbeda nyata $(<0,05)$ untuk semua parameter. Karaginan dari rumput laut Letvuan memiliki nilai rendemen dan kekuatan gel terbaik dibandingkan rumput laut Letman dan Revav, yaitu 43,25\% untuk rendemen dan 207,50 g/ $\mathrm{cm}^{2}$ untuk kekuatan gel. Karaginan dari rumput laut Revav memiliki nilai viskositas terbaik yaitu sebesar 54,39 cP. Karaginan dari rumput laut Letman memiliki kenampakan terbaik dibandingkan dengan Letvuan dan Revav dengan nilai derajat putih sebesar $68,22 \%$. Berdasarkan hasil pengujian, maka hanya karaginan dari lokasi Revav yang memenuhi standar kualitas FAO.
\end{abstract}

KATA KUNCI: Kappaphycus alvarezii, karaginan, Maluku Tenggara, kualitas

\begin{abstract}
Kappaphycus alvarezii is one of the seaweed species (red alga) cultivated in Southeast Maluku. This seaweed species produces carrageenan. The aim of this research was to determine the

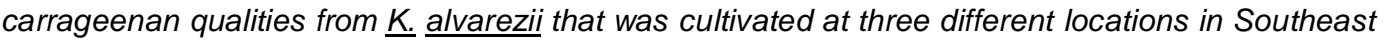
Maluku, which were Letman, Letvuan, and Revav. Carrageenan qualities observed in this reasearch were yield, moisture content, ash content, viscosity, gel strength and whiteness. The seaweed was extracted by alkaline treatment method with $9 \% \mathrm{NaOH}$ solution. The data obtained were analyzed with IBM SPSS Statistics 24 to determine the differences of carrageenan qualities from those three locations. The results showed that the carrageenan from the three locations was significantly different $(<0.05)$ for all parameters. Carrageenan from Letvuan seaweed has the best value of yield and gel strength compared to that of Letman and Revav seaweed, which were $43.25 \%$ for yields and $207.50 \mathrm{~g} / \mathrm{cm}^{2}$ for gel strength. Carrageenan from Revav seaweed has the highest viscosity values among others with values of $54.39 \mathrm{cP}$. Carrageenan from Letman seaweed had the best appearance compared to that of Letvuan and Revav seaweed, with whiteness value equal to $68.22 \%$. Based on the quality test results, only carrageenan from Revav met the FAO quality standard.
\end{abstract}

KEYWORDS: Kappaphycus alvarezii, carrageenan, Southeast Maluku, quality 


\section{PENDAHULUAN}

Rumput laut merupakan salah satu biota laut yang tumbuh dan tersebar di seluruh wilayah perairan Indonesia. Rumput laut juga merupakan salah satu jenis komoditas unggulan budidaya yang dimiliki oleh Indonesia. Pengembangan budidaya rumput laut telah banyak dilakukan di beberapa wilayah perairan Indonesia seperti MalukuTenggara, Sulawesi Selatan, Bali, Lampung, Nusa Tenggara Barat, dan wilayahwilayah lainnya (Darmawan, Utomo, \& Mulia, 2013). Jenis rumput laut yang dibudidayakan di Maluku Tenggara adalah Kappaphycus alvarezii atau biasa dikenal dengan Eucheuma cottonii. Rumput laut jenis ini merupakan salah satu jenis rumput laut penghasil karaginan.

Karaginan merupakan senyawa polisakarida yang diperoleh dari hasil ekstraksi rumput laut merah (Rhodophyceae). Karaginan dibentuk oleh unit Dgalaktosa dan 3,6 anhydrogalaktosa (3,6-AG) yang dihubungkan dengan $\alpha-1,3$ dan $\beta-1,4$ glikosilik secara bergantian (Barbeyron, Michel, Potin, Henrissat, \& Kloareg, 2000; Campo, Kawano, da Silva, \& Carvalho, 2009). Menurut Doty (1985), karaginan berdasarkan kandungan sulfatnya dibagi menjadi dua fraksi yaitu $\mathrm{K}$-karaginan yang mengandung sulfat kurang dari 28 $\%$ dan I-karaginan jika lebih dari $30 \%$. Hilliou et al. (2006) menambahkan bahwa berdasarkan struktur kimia (homopolimer), karaginan dibagi menjadi tiga kategori diantaranya K-karaginan, I-karaginan dan $\lambda$ karaginan. K-karaginan diperoleh dari hasil ekstraksi rumput laut Eucheuma cottonii, I-karaginan diperoleh dari hasil ekstraksi rumput laut Eucheuma spinosum, dan $\lambda$-karaginan diperoleh dari hasil ekstraksi Chondrus crispus (Winarno, 1990). Rumput laut jenis E. cottonii merupakan salah satu rumput laut bernilai ekonomis dan penghasil karaginan jenis kappa yang cukup tinggi.

Karaginan mempunyai kemampuan untuk membentuk gel. Nilai komposisi kimia pada karaginan secara signifikan dapat dipengaruhi oleh suhu dan lama waktu ekstraksi. Kualitas karaginan biasanya dapat dilihat berdasarkan nilai kekuatan gel dan viskositas (Montolalu, Tashiro, Matsukawa, \& Ogawa, 2008). K. alvarezii termasuk dalam golongan Rhodophyta yang menghasilkan florin starch. Sifat pembentukan gel pada rumput laut jenis ini dibutuhkan untuk menghasilkan pasta yang baik (Winarno, 1990).

Karaginan dapat dimanfaatkan dalam berbagai bidang usaha seperti usaha dalam bidang industri pangan dan non-pangan, farmasi maupun kosmetik. Karaginan dalam industri pangan memiliki fungsi yang sangat penting di antaranya sebagai emulsifier, pengental (Velde, Lourenco, Pinheiro, \& Bakker,
2002), dan pembentuk gel (Campo et al., 2009). Oleh karena itu, dalam kimia pangan karaginan biasa disebut juga dengan emulsifier, stabilizer, koloid atau gum (Necas \& Bartosikova, 2013). Karaginan digunakan dalam banyak produk susu, keju, yogurt, permen, es krim dan produk cokelat (Necas \& Bartosikova, 2013). Menurut Rasyid (2003), penggunaan karaginan dalam industri makanan tergantung pada beberapa sifat yaitu kelarutan, viskositas, kekuatan gel, reaktivitas dengan protein, dan sinergisme dengan polisakarida yang bukan gel. Dalam bioteknologi, karaginan sering digunakan sebagai gel untuk melumpuhkan sel/enzim (Velde et al., 2002). Sedangkan dalam pengobatan eksperimental, karaginan digunakan untuk pengujian obat anti-inflamasi (Zacharopoulus \& Philips, 1997).

Di Maluku Tenggara, cukup banyak masyarakat di desa-desa pesisir yang membudidayakan rumput laut. Bibit rumput laut yang biasa ditanam oleh masyarakat awalnya adalah bibit rumput laut lokal kemudian beberapa tahun terakhir mulai masuk bibit rumput laut hasil kultur jaringan. Sampai saat ini terdapat dua jenis bibit yang ditanam oleh masyarakat Maluku Tenggara; yaitu lokal dan kultur jaringan. Secara teknik, budidaya rumput laut di Maluku Tenggara telah dilakukan dengan baik, tetapi proses pemanenan dan penanganan pasca panen masih perlu perbaikan. Pemanenan rumput laut sebelum umur panen masih dilakukan oleh beberapa petani sehingga akan mempengaruhi kualitas dari rumput laut tersebut. Informasi terkait kualitas karaginan murni dari rumput laut $K$. alvarezii di beberapa lokasi yang dibudidayakan di Maluku Tenggara belum ada sehingga perlu dilakukan studi untuk mengetahui seberapa baik kualitas karaginan yang dihasilkan dari budidaya rumput laut yang ada di Maluku Tenggara. Hasil penelitian ini diharapkan bisa memberikan informasi terkait kualitas karaginan dari rumput laut $K$. alvarezii yang ada di Maluku Tenggara dan dapat menjadi pertimbangan untuk pengembangannya lebih lanjut.

\section{BAHAN DAN METODE}

\section{Bahan}

Sampel rumput laut diambil dari tiga lokasi budidaya rumput laut yang berbeda di perairan Maluku Tenggara. Lokasi tersebut antara lain Letman, Letvuan dan Revav. Rumput laut yang digunakan dalam penelitian ini rata-rata berumur 35-40 hari. Rumput laut yang diperoleh dari lokasi Letman dan Revav merupakan hasil budidaya dengan bibit lokal dari perairan Maluku Tenggara sedangkan rumput laut yang diperoleh dari lokasi Letvuan merupakan hasil 
budidaya dengan bibit kultur jaringan. Rumput laut diambil di 3 titik berbeda di setiap lokasi budidaya, dicuci bersih dengan air tawar kemudian dikeringkan di bawah sinar matahari kurang lebih 3-5 hari. Titiktitik lokasi pengambilan sampel dapat dilihat pada Gambar 1. Bahan kimia yang digunakan antara lain $\mathrm{NaOH}$ pro-analysis, isopropanol, aquadest, dan $\mathrm{pH}$ meter.

\section{Metode}

\section{Proses ekstraksi}

Metode ekstraksi mengacu pada penelitian Marseno, Medho, dan Haryadi (2010) dengan sedikit modifikasi. Sampel rumput laut kering seberat $40 \mathrm{~g}$ dipotong kecil-kecil kemudian ditambahkan aquades dengan perbandingan 1:40, yaitu setiap $1 \mathrm{~g}$ rumput laut kering ditambahkan aquadest sebanyak $40 \mathrm{ml}$. Ekstraksi dilakukan dalam suasana basa dengan menambahkan larutan $\mathrm{NaOH}$ konsentrasi $9 \%$ hingga mencapai pH 9-10 selama 2-3 jam pada suhu 80-90 ${ }^{\circ} \mathrm{C}$. Hasil pemasakan yang berupa bubur rumput laut kemudian disaring dengan kain saring ukuran mesh 100 dengan bantuan filter pump. Filtrat yang dihasilkan kemudian diendapkan (presipitasi) dengan larutan isopropanol dengan perbandingan (1:2) hingga terbentuk serat-serat karaginan. Serat karaginan tersebut disaring untuk memisahkan dari larutan isopropanol, kemudian dikeringkan di dalam oven selama 6-7 jam pada suhu $60^{\circ} \mathrm{C}$. Serat karaginan yang sudah kering kemudian dihaluskan dengan blender hingga menjadi tepung karaginan.

\section{Pengujian kualitas air (Akib, Litaay, Ambeng, \& Asnady, 2015)}

Kualitas perairan dimungkinkan mempengaruhi kualitas karaginan yang terkandung pada rumput laut. Oleh karena itu, untuk mengetahui kualitas perairan tersebut dilakukan pengukuran beberapa parameter kimia kualitas air antara lain $\mathrm{pH}$, DO, salinitas, dan TDS menggunakan water quality checker(WQC), dan untuk parameter fisikanya antara lain suhu, kecerahan, kedalaman, dan kondisi lingkungan.

\section{Pengujian sampel}

Pengujian sampel dilakukan untuk mengetahui kualitas tepung karaginan. Parameter yang diuji untuk kualitas karaginan antara lain rendemen yang diperoleh dari berat karaginan kering yang dihasilkan dibagi dengan berat rumput laut kering yang diekstrak dikali 100\% (AOAC, 1995), kadar air (AOAC, 1995), kadar abu (AOAC, 1995), viskositas (FMC Corp, 1977), kekuatan gel (FMC Corp, 1977), dan derajat putih dengan menggunakan alat digital colorimeter yang ditunjukkan dengan nilai $L^{*}, a^{*}, b^{*}$, dimana $L^{*}$ (kecerahan), $a^{*}$ (kemerahan/kehijauan), dan $b^{*}$ (kekuningan/kebiruan). Derajat putih dihitung menggunakan persamaan berikut (Pangastuti, Affandi, \& Ishartani, 2013):

$$
\text { Derajat Putih (DP) }=100-\left[\left(100-L^{*}\right)^{2}+a^{* 2}+b^{* 2}\right]^{1 / 2}
$$

Analisa dilakukan sebanyak 3 ulangan dan data yang diperoleh dianalisa secara statistik dengan ANOVA menggunakan program IBM SPSS Statistics 24.

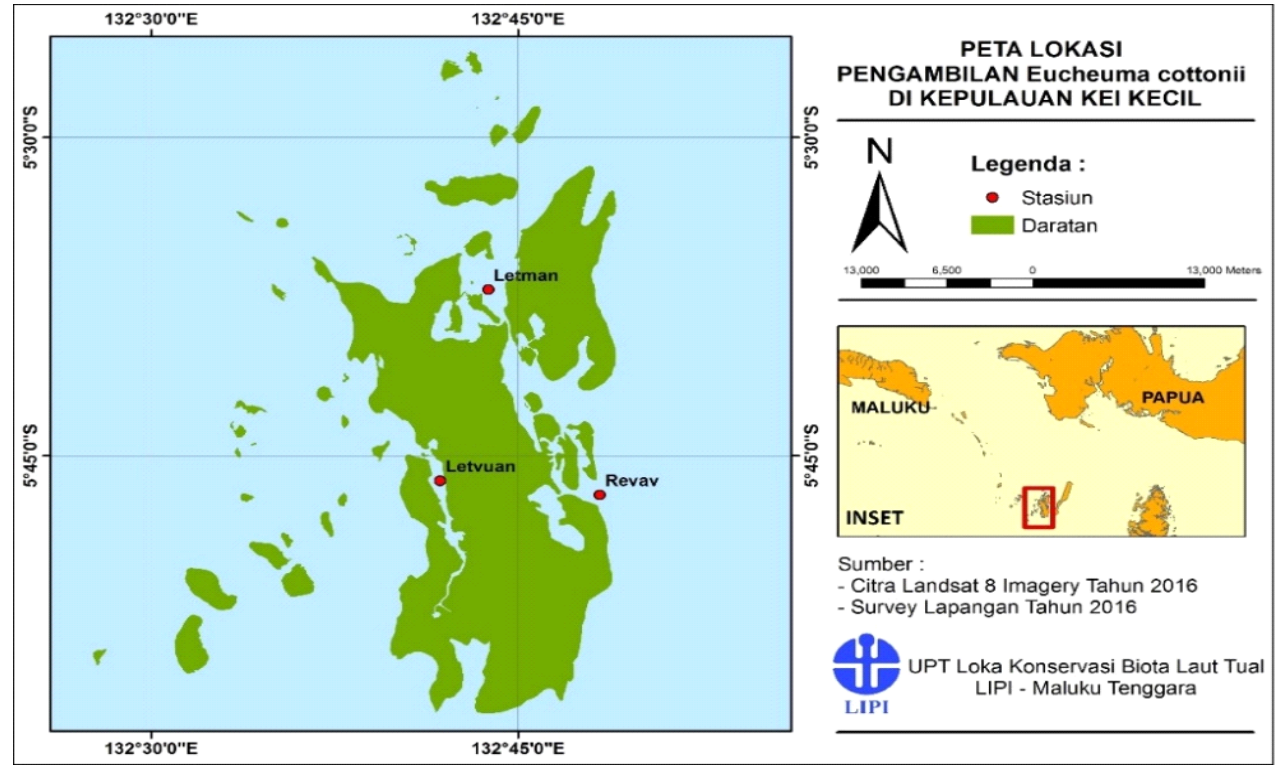

Gambar 1. Lokasi pengambilan sampel rumput laut $K$. alvarezii

Figure 1. Sampling sites of the seaweed $\underline{K}$. alvarezil 


\section{HASIL DAN PEMBAHASAN}

\section{Kualitas Air Lokasi Pengambilan Sampel}

Pengukuran kualitas air di lokasi budidaya rumput laut dilakukan untuk mengetahui kondisi perairan tersebut. Pengukuran kualitas air meliputi dua parameter yaitu parameter kimia dan fisika. Hasil pengukuran kualitas air dapat dilihat pada Tabel 1.

Secara umum kondisi perairan di setiap lokasi pengambilan sampel adalah baik, di mana nilai $\mathrm{pH}$, DO, suhu, salinitas, dan TDS masih dalam kondisi normal. Oleh karena itu lokasi tersebut masih layak untuk budidaya rumput laut. Sebagai perbandingan, penelitian yang dilakukan oleh Akib et al., (2015) di Perairan Selayar menunjukkan bahwa suhu perairan berkisar antara $29,0-30,7^{\circ} \mathrm{C}$ dengan salinitas berkisar antara 29-31,5 ppt. Perairan tersebut berada dalam kisaran yang mendukung untuk dilakukannya budidaya rumput laut. Kandungan oksigen terlarut ketiga lokasi budidaya ini bernilai di atas 5 yaitu berkisar 7,28-8,12, yang sudah sesuai dengan baku mutu perairan sehingga ideal untuk budidaya rumput laut. Menurut Keputusan Menteri Lingkungan Hidup (2004), baku mutu suhu untuk biota laut berkisar antara $28-32{ }^{\circ} \mathrm{C}$, salinitas sampai dengan $34 \mathrm{ppt}$ dengan kandungan oksigen terlarut lebih dari 5 . Menurut penelitian Ohno, Nang, dan Hirase (1996), pada suhu perairan di atas $33^{\circ} \mathrm{C}, K$. alvarezii yang dibudidayakan di Vietnam menjadi rapuh dan mengalami penurunan tingkat pertumbuhan hariannya. Dari laporan tersebut, rumput laut $K$. alvarezii yang dibudidayakan akan tumbuh dengan baik pada suhu mulai $27-30^{\circ} \mathrm{C}$ di perairan tropis.

Kedalaman perairan dari 3 lokasi budidaya yang ada rata-rata $5 \mathrm{~m}$ dengan kecerahan perairan sangat jernih/tampak dasar, sehingga cukup ideal untuk budidaya rumput laut. Kedalaman perairan berkisar 6,5-1,5 m dengan kecerahan perairan berkisar 1,61$6,51 \mathrm{~m}$, berdasarkan perhitungan matrik kesesuaian menunjukkan bahwa nilai tersebut sesuai untuk budidaya rumput laut (Akib et al., 2015). Kedalaman juga dimungkinkan berpengaruh pada kuantitas karaginan yang akan dihasilkan. Hasil karaginan dari rumput laut meningkat sesuai dengan kedalaman rumput laut yang dibudidayakan (Wenno, Syamsuddin, Zainuddin, \& Ambo-Rappe, 2015).

\section{Rendemen Karaginan}

Nilai rendemen karaginan dari rumput laut sampel dapat dilihat pada Gambar 2. Hasil rendemen menunjukkan bahwa rendemen karaginan terbanyak dihasilkan dari lokasi Letvuan dengan nilai $43,25 \pm 1,19 \%$. Nilai rendemen karaginan terkecil dihasilkan dari lokasi Letman dengan nilai $37,01 \pm 1,11 \%$, kemudian diikuti lokasi Revav sebesar $39,94 \pm 0,46 \%$. Berdasarkan uji lajut LSD, nilai rendemen karaginan dari ketiga lokasi berbeda nyata $(P<0,05)$. Sebagai perbandingan, hasil yang diperoleh pada penelitian Muñoz, Freile-Pelegrín, dan Robledo (2004), yang menggunakan rumput laut strain berbeda menunjukkan nilai rendemen tertinggi $40,7 \%$ untuk strain warna hijau, $32,7 \pm 3,9 \%$ untuk strain warna merah dan $37,5 \pm 1,1 \%$ untuk strain warna cokelat.

Perbedaan umur panen dan jenis rumput laut pada penelitian ini dimungkinkan mempengaruhi rendemen karaginan yang dihasilkan. Nilai rendemen tergantung pada umur panen, jenis rumput laut, dan metode ekstraksi (Hayashi, Paula, \& Chow, 2007; Hung, Hori, Nang, Kha, \& Hoa, 2009; Ohno et al., 1996). Muñoz et al. (2004) menambahkan bahwa jumlah dan kualitas karaginan yang berasal dari budidaya laut cukup bervariasi, tidak hanya berdasarkan varietas, tetapi juga umur tanaman, sinar matahari, nutrien, suhu dan

Tabel 1. Kualitas air di lokasi budidaya rumput laut

Table 1. Water quality of the seaweed cultivation sites

\begin{tabular}{lccc}
\hline & Letman & Letvuan & Revav \\
\hline \multicolumn{2}{l}{ Parameter Kimia/Chemical Parameters } & & \\
\hline pH & 8.16 & 8.06 & 8.19 \\
DO & 7.28 & 7.62 & 8.12 \\
Salinitas/Salinity & 33.40 & 32.10 & 28.50 \\
TDS & 25.30 & 24.40 & 25.20 \\
\hline Parameter Fisika/Physical Parameters & & \\
\hline Suhu/Temperature & 29.30 & 28.70 & 29.60 \\
Kecerahan/Brightness & Tampak dasar/Very clear & Tampak dasar/Very clear & Tampak dasar/Very clear \\
Kedalaman/Depth & $5 \mathrm{~m}$ & $6 \mathrm{~m}$ & $5 \mathrm{~m}$ \\
Gelombang/Wave & $\pm 5 \mathrm{~cm}$ & $\pm 5 \mathrm{~cm}$ & $\pm 5 \mathrm{~cm}$ \\
\hline
\end{tabular}




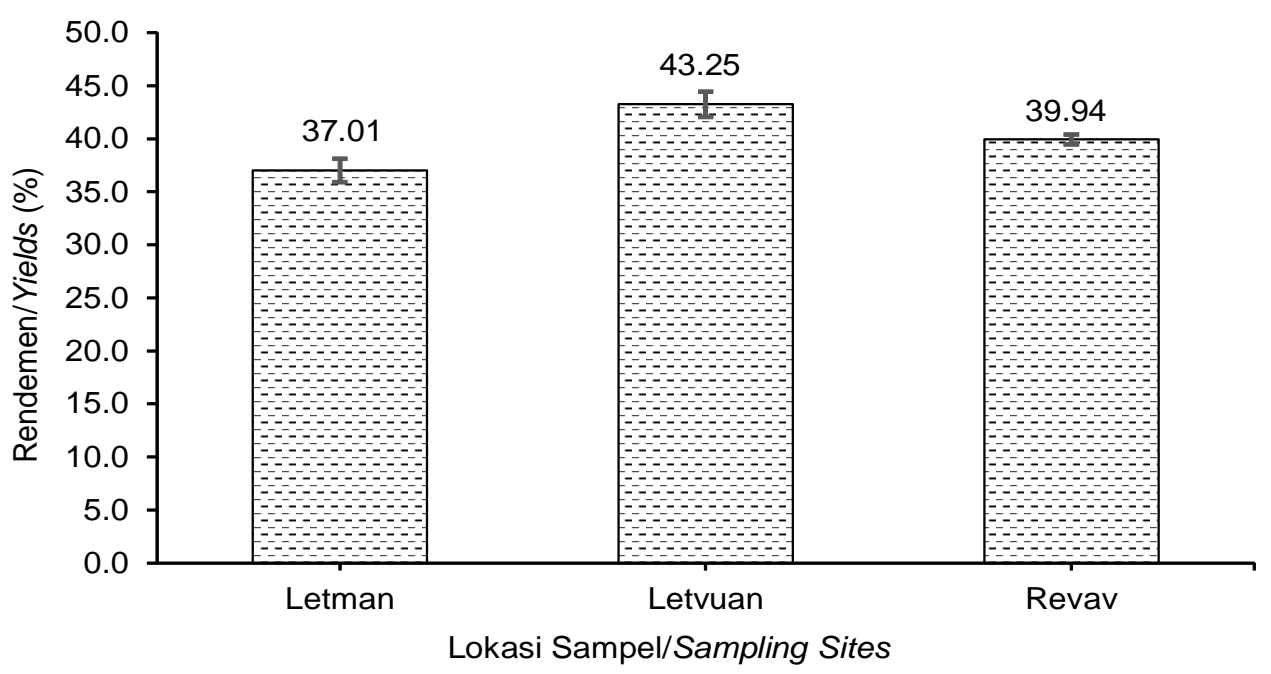

Gambar 2. Rendemen karaginan

Figure 2. Yields of carrageenan

salinitas. Seperti pada penelitian Widyastuti (2010), selama periode 15 hari setelah tanam (HST), kandungan karaginan meningkat dengan cepat sekitar $40 \%$. Setelah periode tersebut, dalam periode tanam sekitar 30 hari, rendemen karaginan bertambah sekitar $10 \%$. Hal ini mengindikasikan bahwa dalam periode tanam setelah 15 hari, pertambahan kadar karaginan sangat lambat, sekitar 0,33\% per hari. Meskipun demikian, proses peningkatan kadar karaginan terus berjalan yang ditunjukkan oleh adanya peningkatan jumlah rendemen karaginan. Marseno et al. (2010), menambahkan bahwa rendemen karaginan pada umur panen 45 dan 60 hari lebih tinggi dibandingkan umur panen 30 hari. Hal ini kemungkinan disebabkan karena respons fisiologis tanaman terhadap kebutuhan karaginan sebagai senyawa penyusun jaringan terjadi secara intensif setelah umur panen 45 hari sampai 60 hari, meskipun kenaikan yang terjadi tidak nyata. Terjadinya perubahan rendemen selama pertumbuhan tanaman diduga merupakan respon fisiologis yang terjadi secara alamiah pada jaringan tanaman. Menurut Hayashi et al. (2007), kondisi karaginan terbaik dapat dicapai bila rumput laut dibudidayakan selama 45 hari.

\section{Kadar Air}

Kadar air merupakan salah satu indikator daya simpan suatu produk. Hasil dari pengukuran kadar air karaginan ini dapat dilihat pada Gambar 3. Nilai rata-rata kadar air karaginan terendah yang dihasilkan sebesar $2,54 \pm 0,01 \%$ pada lokasi Letman, nilai ratarata tertinggi sebesar $4,85 \pm 0,53 \%$ pada lokasi Letvuan,

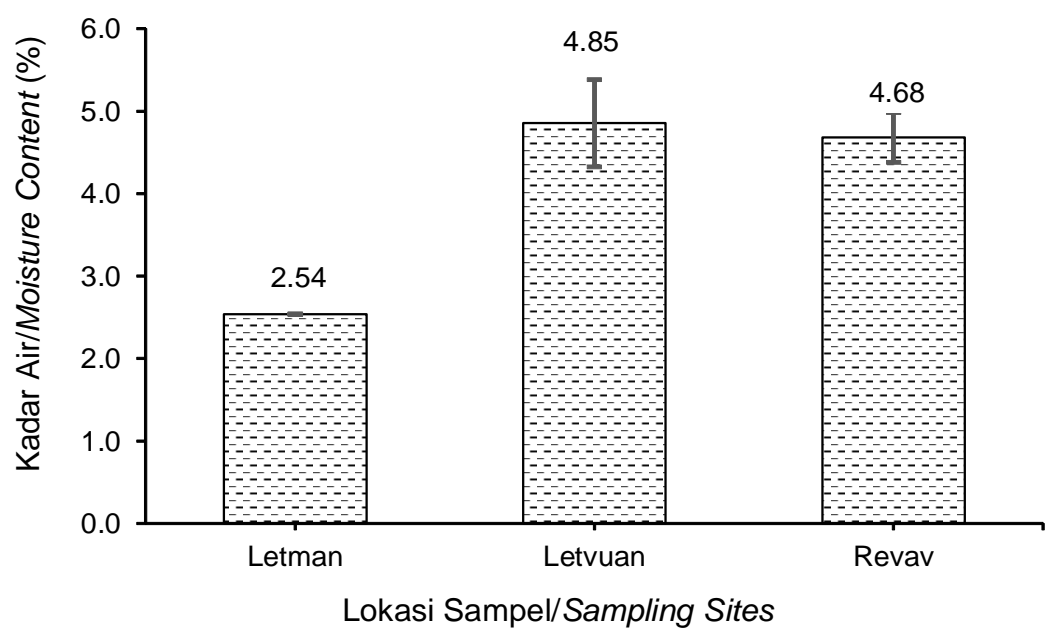

Gambar 3. Kadar air karaginan

Figure 3. Moisture content of carrageenan 
sedangkan lokasi Revav diperoleh kadar air karaginan sebesar 4,68 $\pm 0,30 \%$. Hasil tersebut serupa dengan penelitian Webber, Carvalho, Ogliari, Hayashi, dan Barreto (2012) di mana nilai kadar air karaginan yang

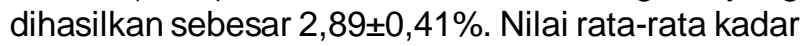
air karaginan dari ketiga lokasi sudah memenuhi standar FAO (2007) yaitu maksimal $12 \%$. Uji statistik kadar air karaginan dari ketiga lokasi menunjukkan hasil yang berbeda nyata $(<0,05)$. Berdasarkan uji lanjut LSD, nilai kadar air dari karaginan Letman berbeda nyata dengan karaginan Letvuan dan Revav, sedangkan karaginan Letvuan dan Revav tidak berbeda nyata $(>0,05)$. Kadar air suatu bahan sangat dipengaruhi oleh proses pengeringan yang dilakukan. Proses pengeringan yang berbeda akan menghasilkan kadar air rumput laut kering yang berbeda pula. Menurut Darmawan et al. (2013), proses pengeringan dengan matahari memerlukan periode pengeringan yang berbeda antar satu produk dengan produk yang lain karena perbedaan intensitas panas selama pengeringan. Faktor yang mempengaruhi kandungan kadar air pada karaginan antara lain sistem pengeringan, sifat bawaan produk seperti adanya ion yang bersifat higroskopis dan adanya faktor perlakuan dalam proses ATC (Basmal, Utomo, \& Sedayu, 2009). Perbedaan umur panen juga mempengaruhi kadar air rumput laut. Penelitian Wenno (2009) menyatakan bahwa pertambahan umur panen menyebabkan kandungan air meningkat. Peningkatan ini disebabkan karena semakin tua umur panen maka jumlah air yang diserap oleh rumput laut semakin banyak, baik sebagai air bebas maupun air terikat. Hal ini menyebabkan jumlah air pada umur panen 55 hari lebih tinggi jika dibandingkan dengan umur panen 50, 45 dan 40 hari. Wenno (2009) juga menambahkan bahwa meningkatnya kandungan air rumput laut berkorelasi positif dengan meningkatnya kandungan air karaginan. Kandungan air pada karaginan yang dihasilkan diduga merupakan air terikat (fisik dan kimia), sedangkan air bebas kemungkinan telah menguap.

\section{Kadar Abu}

Pengukuran kadar abu dilakukan untuk mengetahui banyaknya kandungan mineral yang terdapat dalam karaginan. Nilai kadar abu suatu bahan pangan menunjukkan besarnya jumlah mineral yang terkandung dalam bahan pangan tersebut (Apriyantono, Fardiaz, Puspitasari, Sedamawati \& Budiyanto, 1989). Hasil pengukuran kadar abu dapat dilihat pada Gambar 4.

Kadar abu karaginan ketiga lokasi berkisar antara 20,44-22,68 \%. Nilai terendah adalah karaginan Letman dengan nilai sebesar $20,44 \pm 0,12 \%$ dan tertinggi adalah karaginan Revav dengan nilai $22,68 \pm 0,08 \%$, sedangkan karaginan Letvuan diperoleh nilai $20,98 \pm 0,02 \%$. Nilai kadar abu karaginan ketiga lokasi telah memenuhi standar FAO (2007), di mana nilai kadar abu karaginan tidak kurang dari 15\% dan tidak lebih dari $40 \%$. Hasil uji statistik menunjukkan bahwa nilai kadar abu karaginan ketiga lokasi adalah berbeda sangat nyata $(<0,01)$. Uji lanjut LSD menunjukkan bahwa nilai kadar abu karaginan Letman dengan Letvuan berbeda nyata $(<0,05)$, sedangkan karaginan Letman dengan Revav dan karaginan Letvuan dengan Revav berbeda sangat nyata $(<0,01)$. Hasil berbeda ditunjukkan pada penelitian Harun, Montolalu, \& Suwetja (2013) yaitu kadar abu karaginan yang dihasilkan berkisar antara 14,62-18,41\%,

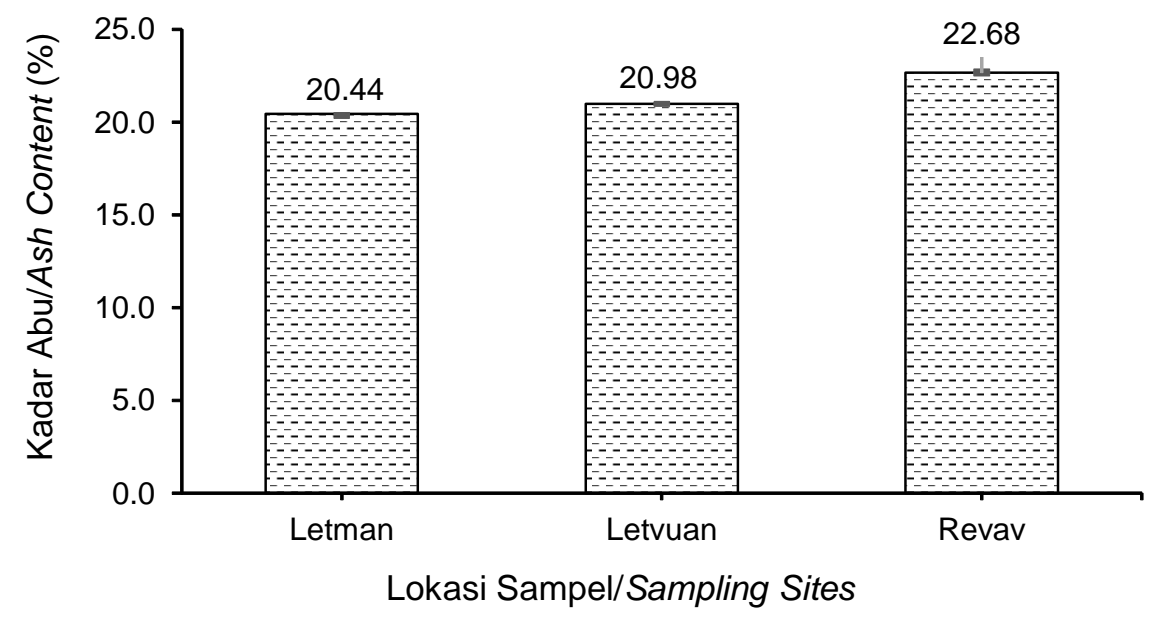

Gambar 4. Kadar abu karaginan Figure 4. Ash content of carrageenan 
sedangkan pada penelitian Kreckhoff, Sukoso, Yanuwiadi, Mangindaan, \& Keppel (2015) diperoleh kadar abu yang lebih tinggi yaitu berkisar antara $35,31 \%-41,63 \%$. Rendahnya kadar abu yang terkandung dalam karaginan kemungkinan disebabkan oleh kurangnya kandungan mineral di lokasi budidaya rumput laut dan rendahnya salinitas di perairan tersebut (Harun et al., 2013). Pada penelitian Kreckhoff et al. ditunjukkan bahwa pada perairan dengan salinitas berkisar antara 29,1-29,7 ppm dan konsentrasi fosfat $0,9 \mathrm{mg} / \mathrm{l}$ dapat menghasilkan karaginan dengan kadar abu yang lebih tinggi dibandingkan dengan perairan yang memiliki nilai salinitas antara 30,1-31,8 ppm dengan fosfat $<0,9 \mathrm{mg} / \mathrm{l}$. Salinitas perairan memainkan peran penting dalam proses osmotik karena kondisi salinitas tinggi akan menghambat proses penyerapan mineral di dalam air (Kreckhoff et al., 2015). Pada penelitian ini, kondisi salinitas perairan berkisar antara 28,5-33,5 ppm.

Kadar abu karaginan juga dipengaruhi oleh umur panen rumput laut. Umur rumput laut yang berbeda pada penelitian ini turut menghasilkan perbedaan kadar abu karaginan. Rumput laut dengan umur panen 55 hari memberikan kadar abu tertinggi dan berbeda nyata dengan rumput laut pada umur panen 40,45 , dan 50 hari. Bertambahnya umur panen cenderung menyebabkan kadar abu karaginan mengalami peningkatan. Rumput laut termasuk bahan pangan yang mengandung mineral cukup tinggi karena kemampuannya dalam menyerap mineral yang berasal dari lingkungannya (Wenno, Thenu, \& Lopulalan, 2012). Tinggi rendahnya kadar abu dipengaruhi adanya garam mineral lain yang menempel pada rumput laut seperti natrium dan kalsium (Winarno, 1990).

\section{Viskositas}

Pengujian viskositas dilakukan untuk mengetahui tingkat kekentalan larutan karaginan pada konsentrasi tertentu. Hasil pengukuran viskositas karaginan dapat dilihat pada Gambar 5 . Nilai viskositas karaginan dari tiga lokasi yang ada berkisar antara 32,24-54,39 cP. Viskositas karaginan terendah dari tiga lokasi sampel adalah karaginan Letvuan dengan nilai $32,24 \pm 1,28 \mathrm{cP}$ dan tertinggi karaginan Revav dengan nilai $54,39 \pm 2,20$ $\mathrm{cP}$, sedangkan karaginan Letman nilai viskositasnya

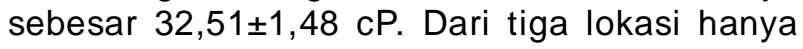
karaginan Revav yang telah memenuhi standar FAO $(50 \mathrm{cP})$. Hasil tersebut hampir sama dengan penelitian Kreckhoff et al. (2015) yang berkisar 30-60 cP.

Umur rumput laut berpengaruh nyata terhadap viskositas karaginan yang dihasilkan. Menurut Widyastuti (2010), viskositas karaginan menurun sejalan dengan bertambahnya umur rumput laut $E$. Cottonii. Wenno (2009) menyatakan bahwa umur panen mempengaruhi viskositas karaginan. Umur panen 40 hari memberikan nilai viskositas tertinggi dan berbeda nyata dengan umur panen 45,50 , dan 55 hari. Penelitian yang dilakukan Marseno et al. (2010) menunjukkan bahwa rumput laut dengan umur panen 45 dan 60 hari dapat menghasilkan karaginan dengan nilai viskositas yang lebih tinggi jika dibandingkan dengan karaginan yang dihasilkan dari umur panen 30 hari. Tingginya viskositas karaginan dengan umur panen 45 hari dibandingkan 30 hari diduga disebabkan oleh kadar sulfat yang terkandung

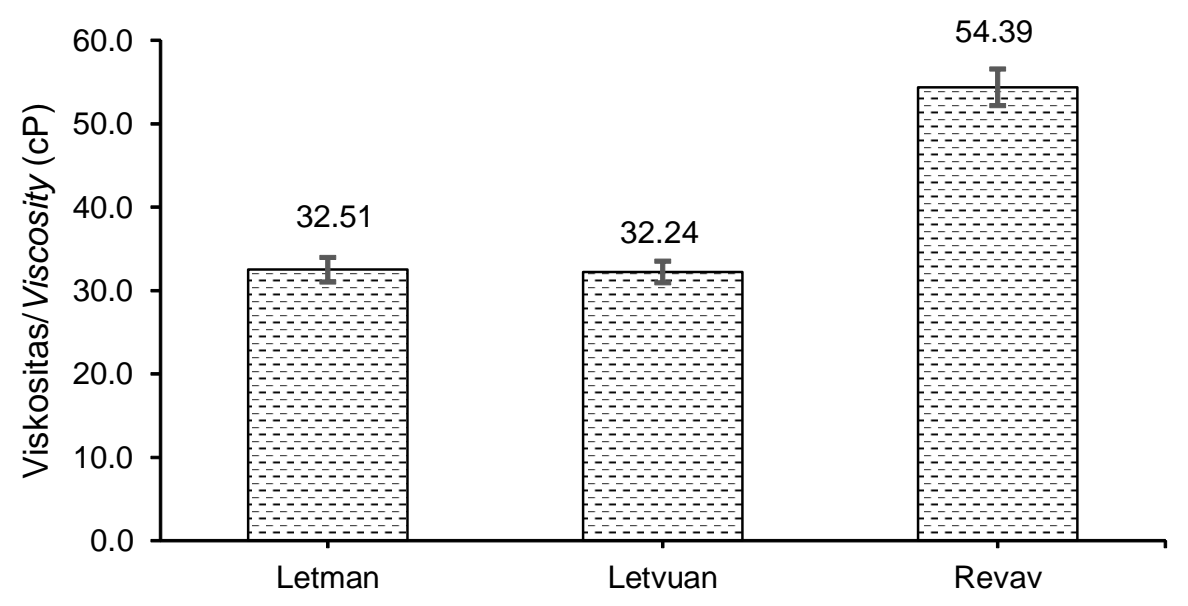

Lokasi Sampel/Sampling Sites

Gambar 5. Viskositas karaginan

Figure 5. Viscosity of carrageenan 
dalam karaginan. Kadar sulfat semakin tinggi sejalan dengan bertambahnya umur rumput laut. Sedangkan menurut Muñoz et al. (2004), perbedaan strain rumput laut tidak memberikan perbedaan yang nyata terhadap nilai viskositas. Akan tetapi, rumput laut dengan tingkat pertumbuhan yang tinggi cenderung menghasilkan karaginan dengan nilai viskositas yang tinggi.

\section{Kekuatan Gel}

Kekuatan gel merupakan salah satu parameter penting yang menentukan kualitas karaginan. Karaginan mampu mengubah cairan menjadi padatan atau mengubah bentuk sol menjadi gel yang bersifat reversible. Kemampuan karaginan dalam membentuk gel dapat dilihat dari seberapa besar nilai kekuatan gel karaginan tersebut. Hasil pengukuran kekuatan gel tersaji dalam Gambar 6 .

Nilai kekuatan gel karaginan dari 3 lokasi berkisar antara 83,83-207,5 g/ $\mathrm{cm}^{2}$. Gambar 6. menunjukkan bahwa kekuatan gel tertinggi adalah karaginan Letvuan dengan nilai rata-rata $207,50 \pm 12,27 \mathrm{~g} / \mathrm{cm}^{2}$, kekuatan gel terendah pada karaginan Letman dengan nilai ratarata $83,83 \pm 5,25 \mathrm{~g} / \mathrm{cm}^{2}$ sedangkan karaginan Revav memiliki nilai sebesar 100,83 $\pm 5,07 \mathrm{~g} / \mathrm{cm}^{2}$. Nilai tersebut masih lebih tinggi dibandingkan penelitian Harun et al. (2013) yaitu berkisar $20-80 \mathrm{~g} / \mathrm{cm}^{2}$, tetapi masih lebih rendah dari penelitian Wenno et al. (2012) yang berkisar antara 196,60 $\pm 5,27-330,00 \pm 5,00 \mathrm{~g} / \mathrm{cm}^{2}$ pada umur panen rumput laut yang berbeda. Hasil uji statistik menunjukkan bahwa nilai kekuatan gel karaginan ketiga lokasi berbeda sangat nyata $(<0,01)$. Berdasarkan uji lanjut LSD karaginan Letman dengan
Letvuan dan karaginan Letvuan dengan Revav berbeda sangat nyata $(<0,01)$, sedangkan karaginan Letman dengan Revav tidak berbeda nyata $(>0,05)$. Kekuatan gel sangat dipengaruhi oleh umur panen. Semakin tinggi umur rumput laut maka nilai kekuatan gel yang dihasilkan cenderung meningkat. Nilai kekuatan gel karaginan akan menurun setelah mencapai puncak pertumbuhan rumput laut (Kreckhoff et al., 2015). Wenno (2009) menyatakan bahwa umur panen juga mempengaruhi kekuatan gel karaginan. Umur panen 50 hari memberikan nilai kekuatan gel tertinggi dan berbeda nyata dengan umur panen 40,45 , dan 55 hari. Semakin tua umur panen kekuatan gel karaginan cenderung meningkat. Pertambahan umur panen akan meningkatkan kandungan 3,6-anhidrogalaktosa dan menurunnya kandungan sulfat. Ditambahkan oleh Yasinta dan Rachmawati (2010), kekuatan gel dari karaginan sangat dipengaruhi oleh konsentrasi pelarut alkali, suhu, dan waktu ekstraksi. Peningkatan kekuatan gel berbanding lurus dengan 3,6 anhidrogalaktosa dan berbanding terbalik dengan kandungan sulfatnya. Semakin kecil kandungan sulfatnya maka kekuatan gelnya akan semakin meningkat.

\section{Derajat Putih}

Pengukuran derajat putih pada karaginan bertujuan untuk mengetahui seberapa besar pengaruh proses ekstraksi yang dilakukan dalam mendegradasi pigmen pada K. alvarezii. Hasil pengukuran derajat putih dapat dilihat pada Gambar 7. Nilai derajat putih terbaik ditunjukkan oleh karaginan Letman dengan nilai ratarata $68,22 \pm 0,46 \%$ kemudian berturut-turut Letvuan dan Revav dengan nilai masing-masing $65,48 \pm 1,99 \%$ dan

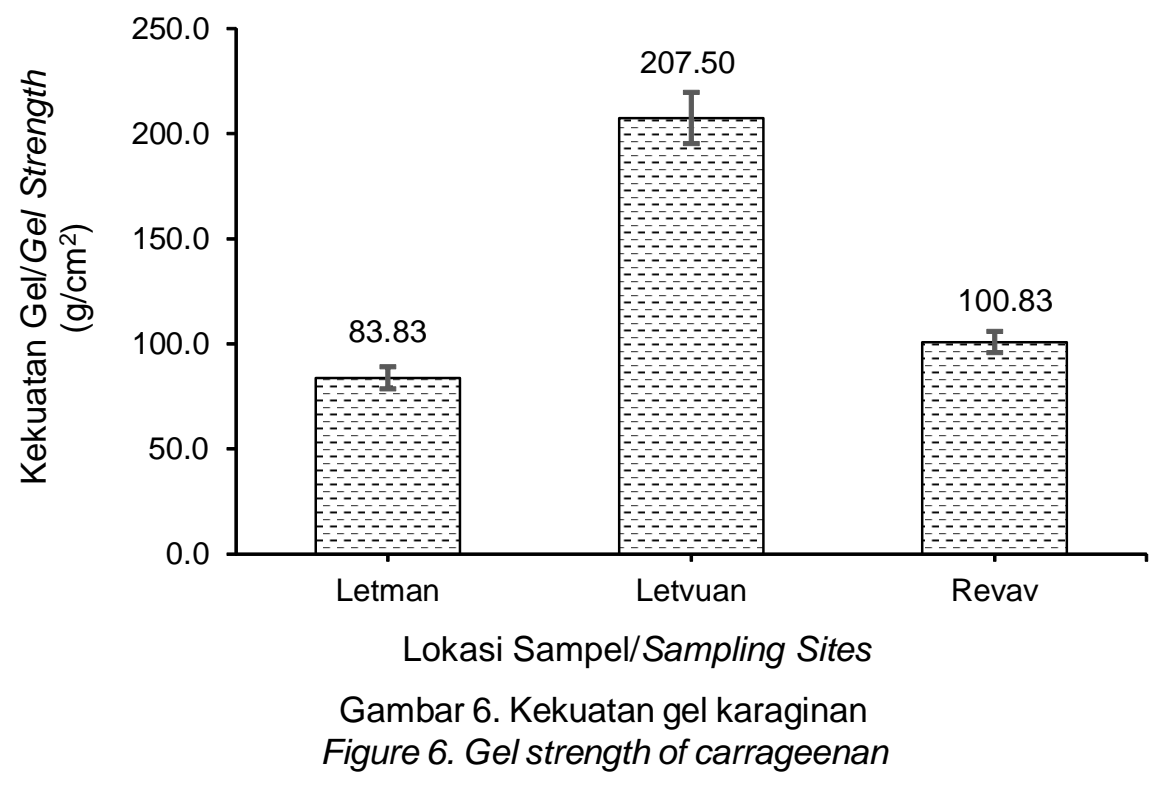




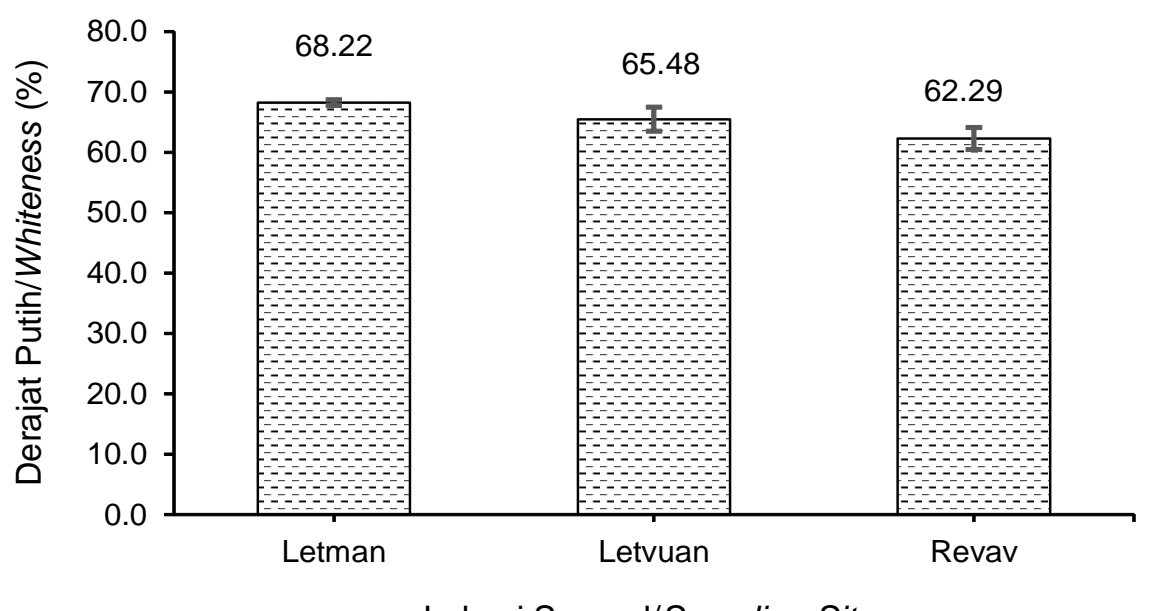

Lokasi Sampel/Sampling Sites

Gambar 7. Derajat putih karaginan

Figure 7. Whiteness of carrageenan

$62,29 \pm 1,85 \%$. Hasil uji statistik menunjukkan perbedaan sangat nyata antara 3 lokasi tersebut $(<0,01)$. Berdasarkan uji lanjut LSD perbedaan sangat nyata terdapat pada karaginan Letman dan Revav $(<0,01)$, sedangkan karaginan Letman dengan Letvuan dan karaginan Letvuan dengan Revav tidak berbeda nyata $(>0,05)$. Derajat putih karaginan merupakan indikator tingkat keputihan warna dari karaginan yang dihasilkan. Semakin tinggi nilai derajat putih tentu semakin baik kenampakan karaginan yang dihasilkan. Pada umumnya, $\kappa$-karaginan bubuk memiliki kenampakan putih atau kuning terang hingga kecoklatan. Nilai derajat putih berkisar antara 0-100, di mana 100 menunjukkan warna putih dan 0 menunjukkan warna hitam (Chan, Mirhosseini, Taip, Ling, \& Tan, 2012).

Kenaikan suhu pada proses pengeringan akan meningkatkan pembentukan warna yang lebih terang dari produk kering. Selain itu pengeringan gel karaginan pada suhu $100{ }^{\circ} \mathrm{C}$ menjadikan produk dengan kelarutan dan kemampuan gelling yang baik (Serowik et al., 2016). Penelitian ini menggunakan suhu $60{ }^{\circ} \mathrm{C}$ untuk pengeringan sehingga mempengaruhi warna akhir karaginan. Warna karaginan dari ketiga lokasi adalah putih kuning hingga kecoklatan. Perbedaan warna karaginan dari ketiga lokasi diduga karena pigmen warna rumput laut awal yang berbeda antar masing-masing rumput laut. Warna kecoklatan pada karaginan dapat disebabkan oleh masih adanya selulosa dan warna (pigmen) alami rumput laut tersebut. Selulosa merupakan serat-serat panjang yang bersama-sama hemiselulosa, pektin dan protein membentuk struktur jaringan untuk memperkuat dinding sel yang terdapat dalam jumlah banyak pada tanaman (Winarno, 2008).

\section{KESIMPULAN}

Karaginan dari rumput laut Letman, Letvuan, dan Revav memiliki kualitas yang berbeda. Karaginan dari rumput laut Letvuan memiliki nilai rendemen dan kekuatan gel terbaik dibandingkan rumput laut Letman dan Revav. Karaginan dari rumput laut Revav memiliki nilai viskositas terbaik dibandingkan yang lain. Karaginan dari rumput laut Letman memiliki kenampakan terbaik dibandingkan dengan Letvuan dan Revav. Secara umum, hanya karaginan dari lokasi Revav yang telah memenuhi standar FAO.

\section{SARAN}

Masih dibutuhkan optimalisasi pada proses ekstraksi untuk memaksimalkan nilai kekuatan gel dan meningkatkan viskositas karaginan serta perlunya memperhatikan waktu panen yang tepat agar karaginan yang dihasilkan dapat maksimal.

\section{UCAPAN TERIMA KASIH}

Penulis mengucapkan terimakasih kepada tim peneliti dan semua pihak yang sudah membantu terlaksananya penelitian.

\section{DAFTAR PUSTAKA}

Akib, A., Litaay, M., Ambeng, \& Asnady, M. (2015). Kelayakan kualitas air untuk kawasan budidaya Eucheuma cottoni berdasarkan aspek fisika, kimia dan biologi di Kabupaten Kepulauan Selayar. Jurnal Pesisir dan Laut Tropis, 1(1), 25-36.

Apriyantono, A., D. Fardiaz, N. L. Puspitasari, Sedamawati \& S. Budiyanto. (1989). Analisis Pangan. PAU Pangan dan Gizi. IPB Press. 
Association of Official Analytical Chemist (AOAC). (1995). Official Methods of Analysis of the Association of Official Analytical Chemist 16th Edition. Gaithersburg, USA: AOAC International.

Barbeyron, T., Michel, G., Potin, P., Henrissat, B., \& Kloareg, B. (2000). i-carrageenases constitute a novel family of glycoside hydrolases, unrelated to that of kcarrageenases. Journal of Bliological Chemistry, 275(45), 35499-35505.

Basmal, J., Utomo, B. S. B., \& Sedayu, B. B. (2009). Mutu semi refineed carrageenan (src) yang diproses menggunakan air limbah pengolahan src yang didaur ulang. Jurnal Pascapanen dan Bioteknologi Kelautan dan Perikanan, 4(1), 1-11.

Campo, V. L., Kawano, D. F., da Silva Jr. D.B., \& Carvalho, I. (2009). Carrageenans: biological properties, chemical modifications and structural analysis - A review. Carbohydrate Polymers, 77, 167-180.

Chan, S. W., Mirhosseini, H., Taip, F. S., Ling, T. C., \& Tan, C. P. (2012). Comparative study on the physicochemical properties of k-carrageenan extracted from Kappaphycus alvarezii (doty) doty ex Silva in Tawau, Sabah, Malaysia and commercial kcarrageenans. Food Hydrocolloids, 30, 581-588.

Darmawan, M., Utomo, B. S. B., \& Mulia, R. A. Y. (2013). The quality of alkali treated cottonii (atc) made from Eucheuma cottonii collected from different regions in Indonesia. Squalen Bulletin of Marine \& Fisheries Postharvest \& Biotechnology, 8(3), 117-127.

Doty, M.S. (1985). Farming the red seaweed, Eucheuma for carrageenans. Micronesica, 9(1), 59-73.

FMC Corp. (1977). Carragenan. Marine Colloid Monograph Number One. Springfield, New Jerney. USA Marine Colloids Division FMC Corporation. 2329.

Food and Agriculture Organization (FAO). (2007). Carrageenan. Prepared at the 68th JECFA \& Published in FAO JECFA Monographs 4. $1-6$.

Harun, M., Montolalu, R. I., \& Suwetja, I. K. (2013). Karakteristik fisika kimia karaginan rumput laut jenis Kappaphycus alvarezii pada umur panen yang berbeda di perairan desa Tihengo Kabupaten Gorontalo Utara. Jurnal Media Teknologi Hasil Perikanan, 1(1), 7-12.

Hayashi, L., Paula, E. J. de, \& Chow, F. (2007). Growth rate and carrageenan analyses in four strains of Kappaphycus alvarezii (Rhodophyta, Gigartinales) farmed in the subtropical waters of São Paulo State, Brazil. Journal of Applied Phycology, 19, 393-399.

Hilliou, L., Larotonda, F. D. S., Abreu, P., Ramos, A. M., Sereno, A. M., \& Goncalves, M. P. (2006). Effect of extraction parameters on the chemical structure and gel properties of K/I-hybrid carrageenans obtained from Mastocarpus stellatus. Biomolecular Engineering, 23, 201-208.

Hung, L. D., Hori, K., Nang, H. Q., Kha, T., \& Hoa, L. T. (2009). Seasonal changes in growth rate, carrageenan yield and lectin content in the red alga Kappaphycus alvarezii cultivated in Camranh Bay, Vietnam. Journal of Applied Phycology, 21, 265-272.
Keputusan Menteri Lingkungan Hidup. (2004). Baku Mutu Air Laut. Menteri Negara Lingkungan hidup, Nomor 51 tahun 2004.

Kreckhoff, R. L., Sukoso, Yanuwiadi, B., Mangindaan, R., \& Keppel, C. R. (2015). Rendemen, gel strength and viscosity of red algae Kappaphycus alvarizii (Doty) in Minahasa Peninsula. Journal of Biodiversity and Environmental Sciences, 7(6), 23-31.

Marseno, D. W., Medho, M. S., \& Haryadi. (2010). Pengaruh umur panen rumput laut Eucheuma cottonii terhadap sifat fisik, kimia dan fungsional karagenan. AGRITECH, 30(4), 212-217.

Montolalu, R. I., Tashiro, Y., Matsukawa, S., \& Ogawa, H. (2008). Effects of extraction parameters on gel properties of carrageenan from Kappaphycus alvarezii (Rhodophyta). Journal of Applied Phycology, 20, 521-526.

Muñoz, J., Freile-Pelegrín, Y., \& Robledo, D. (2004). Mariculture of Kappaphycus alvarezii (Rhodophyta, Solieriaceae) color strains in tropical waters of Yucatán, México. Aquaculture, 239, 161-177.

Necas, J \& Bartosikova, L. (2013). Carrageenan: A review. Veterinarni Medicina, 58(4), 187-205.

Ohno, M., Nang, H. Q., \& Hirase, S. (1996). Cultivation and carrageenan yield and quality of Kappaphycus alvarezii in the waters of Vietnam. Journal of Applied Phycology, 8, 431-437.

Pangastuti, H. A., Affandi, D. R., \& Ishartani, D. (2013). Karakterisasi sifat fisik dan kimia tepung kacang merah (Phaseolus vulgaris I.) dengan beberapa perlakuan pendahuluan. Jurnal Teknosains Pangan, 2(1), 20-29.

Rasyid, A. (2003). Beberapa catatan tentang karaginan. Oseana 28(4), 1-6.

Serowik, M., Figiel, A., Nejman, M., Pudlo, A., Chorazyk, D., \& Kopec, W. (2016). Drying characteristics and some properties of spouted bed dried semi-refined carrageenan. Journal of Food Engineering, 194, 4657.

Velde, F. van de, Lourenco, N. D., Pinheiro, H. M., \& Bakker, M. (2002). Carrageenan : a food-grade and biocompatible support for immobilisation techniques. Advanced Synthesis and Catalysis, 344(8), 815-835.

Webber, V., Carvalho, S. M. De, Ogliari, P. J., Hayashi, L., \& Barreto, P. L. M. (2012). Optimization of the extraction of carrageenan from Kappaphycus alvarezii using response surface methodology. Ciência $E$ Tecnologia de Alimentos, 32(4), 812-818.

Wenno, M. R. (2009). Karakteristik fisiko-kimia karaginan dari Eucheuma cottonii pada berbagai bagian thalus, berat bibit dan umur panen. [Tesis]. Sekolah Pasca Sarjana Institut Pertanian Bogor.

Wenno, M. R., Thenu, J. L., \& Lopulalan, C. G. C. (2012). Karakteristik kappa karaginan dari Kappaphycus alvarezii pada berbagai umur panen. JPB Perikanan, 7(1), 61-67.

Wenno, P. A., Syamsuddin, R., Zainuddin, E. N., \& AmboRappe, R. (2015). Cultivation of red seaweed Kappaphycus alvarezii (Doty) at different depths in 
South Sulawesi, Indonesia. AACL BIOFLUX, 8(3), Yasinta, D. \& Rachmawati, I.D. (2010). Optimasi proses 468-473.

Widyastuti, R. (2010). Sifat fisik dan kimiawi karagenan yang diekstrak dari rumput laut Eucheuma cottonii dan $E$. Spinosum pada umur panen yang berbeda. Agroteksos 20(1), $41-50$. ekstraksi pada pembuatan karaginan dari rumput laut Eucheuma cottoni untuk mencapai foodgrade. Seminar Rekayasa Kimia Dan Proses. Jurusan Teknik Kimia Fakultas Teknik Universitas Diponegoro, Semarang.

Winarno, F G. (2008). Kimia Pangan dan Gizi. Bogor: MBRIO Press. 253 hal.

Winarno, F.G. (1990). Teknologi Pengolahan Rumput Laut. Jakarta: Pustaka Sinar Harapan. 103 hlm.

Zacharopoulus, V.R. \& Philips, D.M. (1997). Vaginal formulations of carrageenan protect mice from herpes simplex virus infection. Clinical and Diagnostic Laboratory Immunology 4(4), 465-468. 
JPB Kelautan dan Perikanan Vol. 13 No. 1 Tahun 2018:21-32 